\title{
SIMPÓSIO INTERNACIONAL COMEMORATIVO AO CENTENÁRIO DA IMIGRAÇÃO JAPONESA NO BRASIL - INTERCÂMBIO CULTURAL ENTRE O BRASIL E O JAPÃO ${ }^{1}$
}

\section{Geny Wakisaka}

Sinto-me muito honrada por ser homenageada neste Simpósio Internacional Comemorativo ao Centenário da Imigração Japonesa no Brasil, organizado pelo Centro de Estudos Japoneses da Universidade de São Paulo e o International Research Center for Japanese Studies (Nichibunken de Kyôto).

Agradeço aos organizadores, esta gentil homenagem à minha pessoa, por ter sido agraciada com o -Primeiro Prêmio Mundial de Nara Man yô-, concedido pela Fundação de Incentivo aos Estudos do Manyôshû, mantida pela província de Nara, no Japão.

Aproveitando os minutos, que me reservaram, gostaria de falar um pouco da minha relação com esta antologia poética japonesa Manyôshû, mas antes devo registrar os meus agradecimentos também aos professores Teiiti Suzuki, e Kensuke Tamai, já falecidos, que me acolheram e ofereceram a oportunidade de desenvolver os meus trabalhos no Centro de Estudos Japoneses da USP.

Já é do conhecimento de todos, mas enalteço o professor Teiiti Suzuki, que estabeleceu as diretrizes do curso de graduação de Língua e Literatura Japonesa da USP. Optando pela compreensão da língua cotejada através da gramática, incentivou a leitura e análise do texto e priorizou o estudo da literatura clássica obrigando-nos à sua leitura no texto original. Foi ele o fundador do Centro de Estudos Japoneses da USP, cujo objetivo era o de criar pesquisadores em língua, literatura e cultura japonesa, com a ajuda do sistema

1. Palavras de agradecimento proferidas na sessão de homenagem pela premiação no "Primeiro Prêmio Mundial Nara Man yô" 
de professores visitantes vindos do Japão. Seu outro objetivo seria o de formar um autêntico centro de estudos japoneses no Brasil.

Devo dar destaque também ao prof. Kensuke Tamai, que o sucedeu na direção do CEJ- USP e foi responsável pelo curso de graduação do curso de Língua e Literatura Japonesa do DLO, que nos incentivou à obtenção de títulos, com bolsas de estudos para o exterior, cuja meta foi a criação do curso de Pós-Graduação desta área.

Meus agradecimentos se estendem também aos professores visitantes, que naquela época, aqui estiveram e me incentivaram nas pesquisas.

Dito isto, falando um pouco da minha trajetória dentro desse esquema, conheci a antologia poética Manyôshû em 1974, aos 48 anos de idade, já casada, com quatro filhos, quando freqüentava bem tardiamente a graduação em Língua e Literatura Japonesa da USP.

Composta de 20 tomos, esta antologia compila mais de 4500 poemas, sendo que o mais antigo deles, de autoria da esposa do imperador Nintoku, data da segunda metade do século V e seu último, vem datado em 1de janeiro de 795. E nela, o que me impressionou muito, além do número elevado de poemas compilados por volta do século VIII, foi o fato de toda ela vir registrada em ideogramas, pois a organização da antologia antecede ao surgimento dos kana, os fonogramas japoneses.

Em 1980, como bolsista da Fundação Japão, assisti às aulas de Pós-Graduação sobre o Manyôshû na Universidade Senshû, no Japão. Retornando ao Brasil, doutorei-me em 1987, com a tese intitulada "O mundo poético de Yoshino nas mutações do poema longo (chôka) japonês.", defendida na área de Teoria Literária e Literatura Comparada. Em 1992, publiquei esta tese com alguns retoques sob o título de "Manyôshû-Vereda do poema clássico japonês."

Indicada pela Diretoria do Centro de Estudos Japoneses da USP e a Fundação Japão de São Paulo, para concorrer ao -Primeiro Premio Mundial de Nara Manyô-, tive a felicidade de ser a escolhida.

Enquanto docente desta Faculdade dei várias aulas falando sobre os poemas clássicos japoneses inclusive sobre o Manyôshû, no Curso de Pós-Graduação, mas ninguém se interessou em seguir a minha trilha. Hoje numa derradeira tentativa, resolvi falar rapidamente sobre um conjunto de cinco poemas de autoria do poeta da Corte Kakinomotono Hitomaro, inseridos no tomo 1, da antologia Manyôshû sob os números 45 ao 49. Estes cinco poemas, um longo, dito chôka, e quatro tanka, poemas curtos, juntos configuram uma abordagem seqüencial sobre a viagem nostálgica empreendida pelo príncipe Karu às planícies de Aki, onde havia um antigo campo de caça, apreciado pelo seu falecido pai, o príncipe Kusakabe. 
Considerado poeta da Corte, presume-se que Hitomaro o tenha acompanhado nessa jornada e oferecido estes poemas escritos por volta dos anos 692 à então Imperatriz Jitô, avó do príncipe Karu.

Falando um pouco sobre os acontecimentos relacionados à Corte de então, a Imperatriz Jitô havia sofrido os infortúnios com o falecimento do seu esposo, o Imperador Tenmu, seguido da morte prematura do seu filho, o príncipe herdeiro Kusakabe. Desfeitos seus sonhos de coroá-lo Imperador, e na eminência de perder o comando da nação, ela decide entronar-se na tentativa de preservar o trono até que seu neto príncipe Karu atingisse a maioridade. E assim fora feito.

O poema longo chôka , 45 diz:

やすみしし 我が大君 高照らす 日の御子 神ながら 神さびせすと 太敷かす 都を置きて こもりくの 初瀬の山は 真木立つ 荒山道を 岩が 根 禁樹押しな心゙ 坂鳥の 朝越えまして 玉かぎる 夕さり来れば み雪降る 安騎の大野に 旗すすき 小竹を押しなべ 草枕 旅宿りせすいにしへ思ひ $\tau$

Cuja tradução literal em prosa, no seu estilo sem pausa seria:

O nosso grande Imperador, que sobre esta terra lidera, conhecedor de todos os seus recantos, Filho do Sol, que das alturas ilumina, de linhagem divina, divinamente se comporta, afasta-se de sua sede imponente para os rincões das montanhas de Hatsuse, seguindo por trilhas de raízes e de pedras expostas, cercado por altíssimos cedros, e demovendo vegetações que impedem sua passagem, ao amanhecer, feito o pássaro que sobrevoa nas alturas, transpõe a montanha, e no lusco-fusco do entardecer em meio às neves que caem,chega às planícies de Aki, onde pernoita, sobre flâmulas de eulálias e folhas dos bambus mirins, e sua mente é tomada pelas reminiscências.

\section{6 安騎の野に 宿る旅人 うち靡き 寝も寝らめやも いにしへ思ふに}

Viajante que pernoita nas planícies de Aki, imbuído em suas reminiscências não terá na certa um sono tranqüilo.

\section{7 ま草刚る 荒野にあれど 黄葉の過ぎにし君が 形見とぞ来し}

Estas são planícies áridas de folhas secas, vejo-as porém como lembranças deixadas pelo senhor.

48 東の 野にかぎろひの 立つ見えて かへり見すれば 月かたぶきぬ

Ao leste da planície vislumbro o nascer do sol, volto-me para o oeste e vejo o desfalecer da lua.

49 日並の 皇子の命の 馬並めて み狩立しし 時は来向ふ 
O momento é chegado em que, de cavalos alinhados partia para a caça, o príncipe alcunhado Sol.

Ao enaltecer a figura do príncipe herdeiro Karu, no poema 45, Hitomaro já o cita como imperador empossado, justapondo-o às figuras de seus antepassados, atribuindo-lhe $o$ status de divindade como indica a mitologia japonesa. E nesta sua asserção um tanto audaciosa, na qualidade de poeta, porta voz da Corte, com disfarce ele legaliza antecipadamente a coroação do príncipe. A viagem do príncipe à procura da imagem viril de seu pai, o afasta da capital, descrita como o lugar seguro, para os longínquos rincões das planícies de Aki. A busca ao passado glorioso do pai é percorrido no entanto, através da paisagem implacável, que se desvenda transtornada pela ausência de quem lá atuava no passado. A memória trilha por caminhos penosos que machucam, e evidenciam os sinais da perda. O tanka 46 reforça o estado emocional do príncipe e no 47 , a paisagem devastada e transfigurada lhe é presenteada como legado do ausente pai. O 48 é a metáfora do ciclo da irremediável troca de gerações e conscientizar o príncipe Karu, do processo irreversível do tempo O poema 49 retrocede mais para o passado, trazendo a imagem do falecido, num momento do amanhecer de um dia em que, com vigor e juventude, ele partia para a caça. $O$ poeta abre e fecha o poema com o amanhecer do presente e do passado, dois momentos de um novo dia.

Abarcando tempos e espaços ilimitados e valendo-se de metáforas e técnicas de justaposições o poeta criou com este conjunto de poemas, as viagens feitas pelos dois príncipes. No 46 e 47, o poeta reanima a imagem do pai, perseguindo a peregrinação do príncipe Karu saudoso no rastro das memórias do pai. No 49, o poeta apresenta aos olhos da Imperatriz, o filho memorizado em tempos de ação e o neto, que já desponta como o seu herdeiro. E no poema 48,com a escalada do sol ao leste e o decair da lua ao leste, não deixa de criar uma imagem infinitamente bela, nela inserindo sua mensagem de veladamente conscientizar a avó imperatriz e o neto, do irreversível processo do tempo.

Finalizo aqui minha fala com esta amostra dos poemas do Manyôshû, na expectativa de que alguém interessado os analise.

E reitero meus agradecimentos por esta homenagem, desejando sucessos à nova geração do CEJ-USP. Muito obrigada. 